\title{
The Tyranny of Participation Revisited: International Support to Local Governance in Burundi
}

\author{
Niamh Gaynor \\ Email: niamh.gaynor@dcu.ie \\ Telephone: 00-353-1-700-6048
}

Author: Dr. Niamh Gaynor is a Lecturer in the School of Law and Government, Dublin City University, Glasnevin, Dublin 9, Ireland.

Acknowledgements: I would like to acknowledge the support provided by TrócaireBurundi for the field research on which this article is based. This support notwithstanding, the analysis presented is my own and in no way reflects the views of Trócaire or any of its partners or affiliates. 


\begin{abstract}
The ubiquitous yet amorphous concept of participation has resulted in much critical debate on its impact and outcomes at both micro (project) and macro (policy) levels. In highlighting what some have termed the 'tyranny' of participation, these debates have also provided valuable insights into how participative spaces might be rendered more transformative. But to what extent have these contributions informed policy and practice on the ground, most particularly within agencies and among practitioners supporting so-called participatory initiatives?
\end{abstract}

Drawing on field research conducted in 2011 on local governance in Burundi, in this article I argue that the lessons and contributions from the literature have failed to impact upon international support to local governance developments in Burundi. Findings on direct and representative participation in local governance structures together with public and official understandings of what such participation means show continuities with the top-down, hierarchical and ultimately marginalising practices of the past. I conclude with some lessons aimed at realising the transformative potential of the opportunities offered by the reforms currently in place. 


\section{Introduction: Community participation: The potential and the pitfalls}

Like it or loathe it, participation as a concept underpinning both micro (project) and macro (policy) level development seems here to stay. From its roots in needs-based development in the 1970s and 1980s to its widespread adoption by mainstream agencies and policy makers in the global shift from governing to governance in the 1990s (Marsh and Rhodes, 1992; Kooiman, 1993), participation has emerged as a core concept underpinning local and national development policies and strategies alike. Its ascension to the mainstream in international development circles is possibly best exemplified by its adoption by the World Bank and other donors as a central concept underpinning both national level Poverty Reduction Strategies Papers (PRSPs) and local level decentralisation programmes adopted in over 80 per cent of developing countries from the 1990s onward. More recently, as criticisms of overly top-down, elite level peace-building strategies in post-conflict zones grows, community-based participatory approaches are also increasingly advocated as part of internationally supported peace-building strategies in these contexts (Berdal, 2009; Autessere, 2010; Kilroy, 2011). For proponents of participation, its advantages lie in its capacity to foster a sense of shared purpose, ownership and responsibility among fractured communities, in the process building social capital and enhancing state legitimacy (see for example DfID, 2006; Brinkerhoff, 2007; World Bank, 2011).

This rapid rise in popularity for participation among policy-makers and practitioners has been accompanied by a lively critical debate on its merits or otherwise. This discussion has been both timely and fruitful in that it has helped lift some of the conceptual haze surrounding this ambiguous 'buzzword' (Cornwall and Brock, 2005) highlighting, on the one hand, its power to radically transform political relations, yet on the other, its potential for exploitation, marginalisation and social control. Some are strident in their criticism, notably the contributors to the provocatively entitled Participation: The New Tyranny? (Cooke and Kothari, 2001) who, focusing largely on micro-level Participatory Rural Appraisals (PRAs), argue that so-called participatory approaches often fail to engage with issues of power and politics, in the process depoliticising local development processes. Others however, through their useful typologies or ladders of participation (see Arnstein, 1969; Pretty, 1995; and White, 1996), highlight the multiple contested meanings of the concept and draw 
attention to the consequent range of outcomes possible. Thus for some, participation may indeed serve to legitimise decisions already made - as many of the contributors to the Tyranny collection assert. For others, it may serve a purely instrumental function, making projects and activities more cost effective by drawing on communities' own resources. And for others again, it may aim at empowerment strengthening communities' confidence and abilities to take decisions, hold political leaders to account and ultimately control their own destinies.

For those interested in this latter, more transformative meaning of participation - and this is where much of the recent peace-building literature appears to point (Berdel, 2009) as well as constituting the central aim of decentralisation (Crawford and Hartmann, 2008; Ogbaharya, 2008) - the critical debate has raised some important issues for consideration. Hickey and Mohan (2004) highlight the importance of understanding the ways in which participation relates to existing power structures and political systems as a basis of moving forward. Cornwall (2008) calls for more focus on participatory initiatives themselves in terms of who participates (and who does not), how they do so, and to what end. Gaynor (2010) emphasises the importance of a vibrant public sphere in highlighting and promoting reflection on the opportunities provided by participatory processes and in maintaining a public spotlight on what happens within them. Eversole (2012), in echoes of Robert Chambers' seminal question 'Whose reality counts?' (Chambers, 1997), challenges community development practitioners and professionals to rethink their assumptions about knowledge, capacity and formal institutions within these spaces. More specifically within African contexts characterised by high levels of distributional inequality, Larson and Ribot (2004) argue that community participation through elected or traditional authorities resembles a modern version of colonial indirect rule - effective as a means of managing labour and resources but ultimately avoiding the politics at the heart of community development. Drawing specifically from a study of natural resource management in Ghana, Marfo (2007) echoes this, arguing that traditional institutions are not necessarily representative of or accountable to the populations over which they preside and that additional mechanisms that open the space for citizen participation are necessary. Taken together, these contributions (and many others) highlight the intensely political nature of participative processes, the real challenges they pose to existing practices and cultures, and, depending on who is 
involved (and informed), how and why, their potential to either transform or consolidate existing political relations. Clearly, there is nothing simple about participation and, for those engaged in or supporting participative processes, there is much to consider. So to what extent have these insights and contributions informed policy and practice on the ground, most particularly within agencies and among practitioners supporting so-called participatory initiatives?

This question forms the basis for this article which draws on fieldwork conducted in 2011 on local governance in Burundi. I present evidence to show that, despite a promising legislative and institutional context explicitly aimed at broad-based community participation in local development, international support to the practical roll-out of local governance reforms has reverted to an instrumental, apolitical, technocratic approach. When considered in an historical context, I argue that such an approach reproduces a dangerous old 'tyranny' - elite manipulation, exploitation and intimidation of communities in the name of 'community participation'.

I develop the argument as follows. In the following section I set out the research design and methodology employed in the study and include an account of my own positionality and standpoint in this regard. In the third section I present a brief historical overview of Burundi's socio-political context together with the governance reforms providing for community participation introduced following the signing of the peace accord of 2000. In the fourth section I present the findings from the fieldwork under five headings - direct community participation; representative participation; public awareness of and engagement in the process; public and official understandings of the participation; and supports offered to the new governance process. I conclude with some practical lessons which may assist in realising the transformative potential of the opportunities offered by legislative and institutional reforms into the future.

\section{Research design and methodology}

The findings presented in this paper draw from a wider study of local governance and peacebuilding in the African Great Lakes region supported by both my own institution, Dublin City University (DCU) and the Irish non-governmental 
organisation (NGO) Trócaire which supports the work of local NGOs and community-based groups in a range of countries in the global South. While I have a long history of collaboration with Trócaire, the study is not a traditional consultancy piece. The research aims, design and methodology are my own and, rather than putting forward specific policy advice and/or recommendations as is common with consultancy research, my approach is to highlight what I feel are significant broader issues leaving Trócaire and its partners to deliberate on what this means for their work on the ground. This particular paper has grown out of ongoing reflection and deliberation with Trócaire on what specifically staff, partners and the people they work with understand by the concept of participation and what this means for their work (including a two-day feedback workshop with Trócaire partners in Burundi, a webinar with Trócaire colleagues working in this area in eight countries worldwide, a presentation and exercise at Trócaire's annual conference in Ireland, and ongoing email discussion). As such, it represents a small (though not insignificant) part of the overall research and develops the conversations that have ensued with Trócaire colleagues over the past year. From my own perspective, the overall research is normatively grounded in my own view (supported by the recent peacebuilding literature cited above) that state-building in fragile states needs to move from a focus on elites and elite-level institutions to an broader focus on inclusive and responsive political society including those heretofore marginalised and, at times, exploited by political elites. The overall research project is designed to include both formal and informal governance arrangements in this conception of political society. Field research in Burundi with both individuals and focus groups began with an exploration of how specific local issues (identified by participants) were addressed within the community. It soon became apparent that issues are either fed through formal mechanisms or not dealt with at all. As no informal governance arrangements were uncovered, the focus turned to the formal process of decentralisation and the opportunities this offers to communities.

Field research for the Burundian case study was conducted by myself with translation from Kirundi to French, where necessary, provided by one of Trócaire's local partners. The research was carried out in January, August and September of 2011 both in the capital Bujumbura and in 8 sites distributed across 5 of the country's 17 provinces. The 8 sites were selected to reflect a cross-section of the country's 
population (in terms of population density, socio-economic conditions, ethnicity, and current levels of low-level conflict). Overall I conducted 36 structured interviews (with 18 women and 18 men selected randomly on transect walks across the sites) and 16 focus groups (gender disaggregated and comprising between 6 and 10 participants) with randomly selected community members across the 8 sites. I later collated and coded the open ended responses to the structured interviews and processed these using SPSS software. The aim of the focus groups was to explore the issues raised in structured interviews in more depth as well as to uncover any other relevant issues not covered by the interview schedule. In addition, I conducted 8 semi-structured interviews with local (commune and hill level) officials and 9 semi-structured interviews with international and national level donors, ministry officials, NGO representatives and commentators in Bujumbura. I also collated and analysed relevant legislative and policy material. While this paper deals with just one aspect of the research, broader research findings are presented and analysed elsewhere (see Gaynor, 2011 and Gaynor, 2013).

\section{Burundi: A troubled past and an uncertain future}

Burundi is a small, densely populated country in central Africa. It is also one of the poorest, most inequitable and most insecure regions on the continent. Since attaining independence in 1962 the country has been plagued by internal conflict and violence, most recently a civil war which, breaking out in 1993, lasted over ten years. Involving widespread human rights violations, this has resulted in the social, economic and political exclusion of wide swathes of the country's population.

In the shadow of its neighbour Rwanda, there is a popular tendency to attribute the country's problems to ethnic grievances alone (like Rwanda, Burundi possesses few natural resources). However, more systematic analyses within the literature argue that that the causes of poverty, insecurity and conflict are more complex (Hammouda, 1995; Lemarchand, 1996; Ndikumana, 2000; Ngaruko and Nkurunziza, 2000; Reyntjens, 2005; Uvin, 2008, 2009). For these analysts, the roots and ongoing drivers of the country's problems lie in the state apparatus itself - both the "predatory bureaucracy which cares only for its own interests" (Ngaruko and Nkurunziza, 2000: 
370) and the struggles for economic resources among and across different groups of the political elite. Peter Uvin expresses this succinctly...

This system is at the core of Burundi's problems. It is an institutionalized system of corruption, social exclusion, impunity, unpredictability, a total lack of accountability and clientelism. It has gorged itself for decades on aid money. Every Burundian knows this system, in which small groups of people use the state to advance their personal interests. It is the key problem and the main cause of war, not ethnicity or poverty.

(Uvin, 2008: 109-110)

This system both relies on and has resulted in a citizenry which is frequently manipulated and/or intimidated by its leaders, with such manipulation and intimidation facilitated by the strongly hierarchical nature of social and political relations within the country. These relations are rooted in both the county's precolonial monarchy and subsequent colonial rule facilitated, in part, through a rigid, top-down decentralisation structure introduced towards the end of the colonial period in 1959 (see also below) (Hammouda, 1995; Uvin, 2009).

These egregious systemic problems were acknowledged by all involved in the peace negotiations of the late 1990s. A central part of the final peace accord, which involved all but one of the principal rebel groups, was mediated by regional leaders (Julius Nyerere followed by Nelson Mandela) and signed in Arusha, Tanzania in 2000 , was the agreement to introduce a new decentralisation programme aimed at dividing power and resources across rural communities. With assistance thereafter from international institutions, this new programme was written into the new Constitution of March $18^{\text {th }}, 2005$. A Local Government Law was adopted that same year, a Decentralisation Policy was published in 2009, and local institutions were put in place with the first commune levels elections held in 2005 and hill level elections in 2010 .

As the relevant legislative and policy texts set out, this new model of governance envisages "a new state culture, a new politico-administrative spirit within the state..." (Gouvernement de Burundi, 2009: 56) which "aims at the active participation of all the population in defining and implementing economic and social development policies in their localities." (Gouvernement de Burundi, 2009: 10). In theory 
therefore, the newly introduced programme is aimed at a radical political transformation, offering numerous opportunities for downward accountability and active citizen voice and participation in local affairs. But how do these radical policy and institutional developments play out in practice and to what extent has international support to the process sustained its historically-rooted, politicallycentred approach? In the following section I set out the principle findings in relation to this question.

\section{Participation in practice: Past tyrannies revisited?}

The principle findings in relation to how participation is playing out in practice on the ground are set out in this section. Following the issues introduced in the first section, the findings are presented under five main headings: direct community participation; representative participation; public awareness of and engagement in the new institutions; public and official understandings of participation in this context; and supports offered to the new governance reforms.

\section{Direct community participation}

A range of provisions for direct community participation are set out in the Local Government Law of 2005. At commune level, council meetings, held three times a year, should be open to the public and minutes and decisions reached at these meetings should be posted on notice boards outside commune offices (Articles 10, 19 Gouvernement de Burundi, 2005). In addition, an annual progress report prepared by the commune Administrator should be made publicly available (Article 31). Twice a year, direct community participation should be assured through public meetings between elected council members and local communities where participants may pose questions and propose ideas to commune council members (Article 15). At the more local hill level, heads of hill councils should organise public meetings for all hill residents at least three times a year to collectively analyse local issues (Article 37).

Although local officials are well aware of these provisions for direct community participation listing them in detail in interview when asked, few of these actually take place. Of the 8 commune offices visited, just 2 had any relevant information posted on their notice boards. One had posted a notice (in French which is not widely 
spoken) of an upcoming meeting, while the other had, in line with the procedures set out, posted a record of deliberations and decisions taken from the previous meeting. None of the 8 communes visited had disseminated information on their annual budgets and none had carried out the required public meetings. An exception to this are specific public meetings organised and attended by the administrative head of the commune council (Administrator) alone where the community is mobilised to collect taxes for specific local development projects determined by the commune council. This pattern is mirrored again at hill level where, of the 22 hill councils examined, council committee meetings were reported to be sporadic and no hill councils had held public meetings with communities. Once again, an exception to this was meetings held to collect taxes and organise local community labour for specific projects as instructed by the commune Administrator. When asked why meetings between elected officials and communities allowing for direct community participation beyond tax collection and labour mobilisation were not held, officials responded that such meetings prove too costly and no revenue has been made available to hold them.

\section{Representative participation}

In the relative absence of opportunities for direct community participation I also explored the efficacy of representative participation at both hill and commune level. As I have already noted, commune and hill level elections in 2005 and 2010 respectively allow for participation through elected representatives. The efficacy of this representation was explored by examining who these representatives are and how they represent their communities. The party politicisation of the process at commune level - where candidates run in a grouping on a party list rather than as individual candidates - means that all commune representatives are active party members, accountable to their party superiors as much as, if not more than, their constituents. All councillors interviewed have been active party members for some time and spend more time in the capital than in their communes. The only publicly accessible representative appears to be the Administrator and s/he appears to be only accessible to a limited number of people on an individual basis. Of the 162 hill residents involved in this research, just 5 (4 men and 1 woman) have consulted with their Administrator over particular matters (the woman consulted a female Administrator). 
Each of these 5 live in or in the vicinity of the commune centre. For many others, in the words of one resident, "it [the commune council] is for people at a higher level" and many noted that it is not possible to personally access commune council members as only heads of the hill council or those with specific contacts can do this.

The situation is somewhat different at the more local hill level where councils are made up of local non-party representatives who pose their candidature on an individual basis. However, many of the newly elected representatives are traditional authorities and leaders from past systems. Indeed, despite the radical new vision of the reforms, one of the most popular qualities in a local representative sought by voters interviewed (along with honesty and integrity) was a track-record and experience of 'administration'. The result appears to be a narrow and selective form of representation, mirroring that at commune level. Only 6 out of the 162 residents consulted (4 men, 2 women) stated that they have gone to their hill council with issues to be resolved (the issues were disputes with neighbours over land boundaries ( 3 male); theft in the home ( 1 male, 1 female); and family disputes arising from the widespread practice of 'polygamy' or wife abandonment (1 female)). For those that have not approached their hill council, when asked why not, some noted that they have not yet had issues which need resolution, while others (predominantly women) pointed out that the issues they face are of no interest to their (predominantly male) council members.

\section{Public awareness of and engagement in the process}

The findings so far may appear somewhat surprising given the radical, transformative aspiration of the governance reforms. Yet investigations into public awareness around these reforms revealed that communities remain largely unaware of them. None of the hill residents interviewed for the research had ever attended either a commune or a hill council meeting or knew that they could. None were aware of the provisions for public meetings and direct community participation within these. Just 30 per cent of the residents interviewed had some idea of the role and activities of the commune council (roles cited were maintenance of peace and order and tax collection). In contrast, 84 per cent of residents interviewed cited roles for the hill council. The top two roles cited were local conflict resolution and the organisation of 
community labour. Thus, communities largely view their representative bodies as relatively remote top-down authorities regulating local affairs rather than as truly representative portals for their own views, ideas and plans as envisaged within the reform process. This leads on to the question of what the different actors understand by the concept of participation in this context.

\section{Public and official understandings of participation}

Noting that participation was a central concept underpinning local governance reforms at the outset, all actors were asked how they saw community participation being assured within local processes and to what end. For international sponsors of the programme (the EU, the World Bank and Co-operation Suisse), noting the serious shortfall in funding for local community projects, community participation was partly seen as a cost-sharing exercise where, through both labour and financial contributions, communities assist in funding specific projects and activities determined by commune councils or external agencies. This is evidenced in the requirement for counterpart funding (in the form of local financial contributions and labour) for World Bank and the EU funded micro-projects at local level. This interpretation was mirrored by local council officials (at both commune and hill levels) who talked of calling people to public meetings when money was to be collected or community labour / 'community development works' (CDWs - see also below) to be organised. Community participation was thus, once again, viewed as a cost-sharing exercise. As I have outlined above, for local community members themselves both hill and, most particularly, commune councils continue to be viewed more as authorities to be obeyed rather than as bodies to represent community interests. And so many residents interviewed found the question on whether they 'participate' within their local structures difficult to understand. When adjusted to a question on how they 'interact' with these structures, many mentioned participating in CDWs when instructed to do so by their community leaders. For the majority of residents interviewed, this was their sole point of contact with their representative bodies.

While clearly representing an instrumental view of participation, this understanding also reflects the current practice of travaux de développement communautaire' (CDWs) - weekly (from 7am to noon each Saturday) obligatory community labour works organised by local authorities. Every Saturday morning, be it in the state 
capital Bujumbura, or in rural areas across the country, people can be seen working together under the supervision of their local leader in a range of areas - activities include construction, road maintenance, water drainage and anti-erosion measures, well/bore hole maintenance, reforestation/tree planting etc... Although, in theory, everyone over the age of eighteen must report for work, participation in these CDWs appears to be somewhat uneven. During my time in Burundi, I observed more women (including children certainly under the age of eighteen) than men engaged in these works in rural areas, and the absence of Burundi's more affluent citizens both in rural areas and in the capital was apparent week after week. These observations were supported by interview respondents who noted that this is indeed the trend. While, in a country with such limited financial resources, such communal works are certainly useful in maintaining and perhaps even fostering shared ownership of and responsibility for common resources, the roots of this practice in both the colonial and pre-colonial era, where communal works were organised for the benefit of authorities and managed à la chicotte (by the whip) are important to note (see Guichaoua, 1991 and Nsabimana, 1993 for fuller accounts of the continuities of this current practice with those of the past).

Community participation, in the voiceless, powerless, and potentially exploitative form set out here in the form of CDWs represents a significantly different version to that set out in the texts, regulations and provisions underpinning the new decentralisation programme. Indeed, it risks reproducing the old system of decentralisation first introduced by the Belgian authorities towards the end of the colonial period in 1959 and continued following independence in 1962. As the Burundian political scientist Elias Sentamba (2011: 4) has written, this experience was not positive. The system served as a system of political and social control, with authority exercised in a rigidly hierarchical top-down manner and community participation limited to carrying out the orders of local level officials and leaders who in turn reported to Provincial and central authorities.

\section{Participation without politics: The limitations of international support}


Overall therefore, experiences on the ground point to a significant gap between the transformative roots of the reforms and their practical roll-out. The final question which remains is why. With this in mind, I examined the nature of international support to the process. As well as involving the construction of commune offices, election monitoring and support in the preparation and dissemination of relevant texts, ongoing international support involves funding for micro-projects and training workshops for local officials and some select community members. This training is often contracted out to local NGOs, and community members are selected by local officials. Commune Administrators and officials interviewed for this research reported that they participate in, on average, two training workshops of between three and five days a month. This amounts to between a third and a half of officials' total working hours. None of the residents involved in this research had participated in, or were aware of, these workshops.

While it lay beyond the remit of this particular research to comprehensively evaluate these workshops, interviews with both international sponsoring agencies and local NGOs contracted to carry out the training revealed that the focus lies very much at an administrative level, aimed at putting in place policies and procedures to account for budget spending rather than dealing with the more political transformations required. Administrators and local officials interviewed re-iterated this, drawing attention to the range of financial and administrative procedures covered by their training when questioned about its content.

This apolitical, technocratic focus in international support has three potential consequences. First, it reinforces traditional political hierarchies by creating insiders and outsiders - 'experts' (the trainers and trainees) and the rest. This is antithetical to the political transformations underpinning the new governance reforms. Second and very much related, the pedagogical style employed reinforces norms and assumptions among official and NGO staff about the superiority of expert knowledge. Indeed, a recent comprehensive evaluation on the training programme run throughout the country by the World Bank is strongly critical of the top-down pedagogical style of trainers (Baltissan and Sentamba, 2011). Rather than adapt their language and techniques to their groups, the evaluators note that trainers consistently deliver the same monotonous and directive 'magisterial speeches'. And so, in an environment 
not conducive to accountability, local elites learn that they now know best, that it is their knowledge and capacity that 'counts', and that there is therefore little to be gained in engaging communities in direct participation through public meetings. And third, the lack of broader public awareness campaigns on the new process means that there is little public debate on or awareness of the new political transformations entailed therein and therefore little incentive to promote them.

\section{Conclusion: Transforming participation - some practical lessons}

A combination of factors has resulted in a gap between the transformative changes envisaged by architects of the new reforms and their practical roll-out on the ground. As the core political ambitions of the reforms have been over-written with a technocratic, administrative focus, the central concept underpinning them community participation in both decision-making and actions at local level - has been lost. Politics, within communes and on the hills, continues as ever, with accountability upward and community participation reduced to obligatory revenue generation and communal labour when demanded by authorities for projects and activities over which communities have no control.

There are four valuable lessons here, both for those supporting the ongoing reforms in Burundi, but also for those interested in transforming participative processes more broadly. The first is that participation is not just about local revenue generation and labour - i.e. cost-sharing. It is inherently political. Failure to acknowledge this in supporting so-called participative processes can undermine both the instrumental and political gains and reinforce old inequalities and tyrannies. This means moving beyond participation as cost-sharing and paying attention to the existing cultures and practices into which it is introduced, thinking carefully about how to interact with these. The second is that participation does not happen automatically. If you build it (a 'participative' process/structure), 'they' will not just come. For traditional powerholders, participation means ceding a degree of power and control. In a system benefitting them disproportionately, clearly this will not happen easily. There will be no supply without demand. Supporters of participative processes need therefore to think about how to stimulate this demand. Rather than resorting to traditional 
lobbying techniques, this may mean both raising public awareness of the opportunities and engaging with communities to learn what forms of participation prove most appropriate and useful to them (if indeed any). The third is that participation never happens evenly. It is often the powerful, the well-connected, the already advantaged who take their place at the table. An unreflective application of the now widely critiqued model of procedural democracy means that there is never a place for everyone. Reflecting a growing interest in post-liberal, more substantive models of democracy (see for example Mouffe, 1996; Young, 2000), the question to ask therefore is perhaps not so much 'who participates?', nor even 'who do they represent?', but rather 'how do they represent (their people/constituents)'? How do they mediate their interests and ambitions? Are they effective in this? And the final lesson is that support to such processes requires a new form of engagement with communities - beginning by talking with them, not at them. If you build it and they (the community) do not come, they probably have extremely good reasons for not doing so. Meaningful support to participatory processes entails beginning where people are at and moving on from there. For followers of traditional, mainstream views about knowledge and capacity (entrenched within the international development industry), this may well prove a challenge.

The governance reforms introduced worldwide over the last two decades offer significant opportunities for meaningful, transformative participation, affording communities - in many cases for the first time - a real say in their own futures. While some analysts and commentators remain cynical and argue that these reforms represent yet another step in a relentless Western-driven neo-colonisation of the majority world, Burundian civil society activists see real potential in these developments and are keen to colonise these spaces themselves, transforming their own political society. However, as this and as other cases have shown, if the opportunities available are not seized, supported and built upon in a politically and historically sensitive manner, they risk reproducing old tyrannies and abuses, in the process further alienating communities and undermining the effectiveness and sustainability of community development investments and initiatives. The challenges are clearly great. But so are the potential gains. Within a progressive legislative and institutional context, it now falls to professionals and practitioners to interrogate their 
own values, frameworks and practices in working with states and communities to meet these challenges. 


\section{References}

Arnstein, S. (1969) "A ladder of participation", American Institute of Planners Journal, 69, 216-224.

Autesserre, Séverine (2010) The Trouble with the Congo: Local Violence and the Failure of International Peacebuilding, Cambridge and New York: Cambridge University Press.

Baltissen, G. and E. Sentamba (2011) Programme et Plan d'action opérationnel de renforcement des capacités des acteurs en charge de la mise en æuvre de la politique de la décentralisation et du développement communautaire, Evaluation indépendante du PRADECS, Bujumbura: PRADECS.

Berdal, Mats (2009) Building Peace after War, London and New York: Routledge.

Brinkerhoff, D.W. (2007). Governance in Post-Conflict Societies: Rebuilding Fragile States London, London and New York: Routledge.

Chambers, R. (1997) Whose Reality Counts: Putting the First Last, London: Intermediate Technology Productions.

Cooke, B. and U. Kothari (2001) "The Case for Participation as Tyranny", in Participation: The New Tyranny?, B. Cooke and U. Kothari (eds.), London and New Work: Zed Books.

Cornwall, A. (2002) "Making spaces, changing places: Situating participation in development", IDS Working Paper 170, Sussex: Institute for Development Studies.

Cornwall, A. (2008) “Unpacking 'Participation': models, meanings and practices", Community Development Journal, 43(3), 269-283.

Cornwall, A. and K. Brock (2005) "What do buzzwords do for development policy? A critical look at 'participation', 'empowerment' and 'poverty reduction'", Third World Quarterly, 26(7), 1043-1060.

Crawford, G. and C. Hartmann (eds.) (2008) Decentralisation in Africa: A Pathway out of Poverty and Conflict?, Amsterdam University Press: Amsterdam.

DfID (2006) Eliminating World Poverty: Making Governance Work for the Poor: White Paper on International Development, London: Department for International Development.

Eversole, Robyn (2012) "Remaking participation: challenges for community development practice”, Community Development Journal, 47(1), 29-41

Gaynor, N. (2010) Transforming Participation?: The Politics of Development in Malawi and Ireland, Basingstoke: Palgrave. 
Gaynor, N. (2011) Opportunities for Citizen Participation in Local Governance in Burundi, Research report prepared in collaboration with Trócaire-Burundi, available at http://doras.dcu.ie/16691/.

Gaynor, N. (2013) "Supporting Decentralisation in Fragile States: A View from Burundi”, Development Policy Review (forthcoming).

Gouvernement de Burundi (2005) Loi no. 1/016 du 20 avril 2005 portant organisation de l'administration communale, Bujumbura.

Gouvernement de Burundi (2009) Document de Politique Nationale de Décentralisation au Burundi, Bujumbura.

Gouvernement de Burundi (2011) Manuel de Procédures Administratives et Financières, Bujumbura.

Guichaoua, A. (1991) “Les 'travaux communautaires' en Afrique Central, TiersMonde, 32(127), 551-573.

Hammouda, B. (1995) Burundi: Histoire Economique et Politique d'un Conflit, Paris: l'Harmattan.

Hickey, S. and G. Mohan (2004) "Towards participation as transformation: Critical themes and challenges", in Participation: From Tyranny to Transformation, S. Hickey and G. Mohan (eds.), London and New York: Zed Books.

Human Rights Watch (2010) We'll Tie You Up and Shoot You: Lack of Accountability for Political Violence in Burundi, Geneva and New York: Human Rights Watch.

Kilroy, W. (2011) "From conflict to ownership: Participatory approaches to the reintegration of ex-combatants in Sierra Leone", Irish Studies in International Affairs, 22, 127-144.

Kooiman, J. (1993) Modern Governance: New Government-Society Interactions, London: Sage.

Larson, A.M. and J.C. Ribot (2004) "Democratic decentralisation through a natural resource lens: an introduction", European Journal of Development Research 16(1): 125 .

Lemarchand, R. (1996) Burundi: Ethnic Conflict and Genocide, Washington: Woodrow Wilson Centre.

Marfo, E. (2007) "Institutionalising citizen participation and community representation in natural resource management: Lessons from the Social Responsibility Agreement negotiation in Ghana", Community Development Journal, 43(4), 398-412.

Marsh, D. and R.A.M. Rhodes (1992) Policy Networks in British Government, Oxford: Clarendon Press. 
Mouffe, C. (1996) Democracy, power and the political, in: S. Benhabib (Ed.) Democracy and Difference, Princeton, NJ: Princeton University Press.

Ndikimana, L. (2000) "Towards a solution to violence in Burundi: A case for political and economic liberalisation", The Journal of Modern African Studies, 38(3), 431-459.

Ngaruko, F. and J.D. Nkurunziza, (2000) "An Economic Interpretation of Conflict in Burundi”, Journal of African Economies, 9(3), 370-409.

Nsabimana, F. (1993) "Le contrôle de la main d'oeuvre au Burundi", Revue Internationale d'Anthropologie et de Sciences Humaines, 41(2), 307-327.

Ogbaharya, D. (2008) "(Re-)building governance in post-conflict Africa: the role of the state and informal institutions", Development in Practice, 18(3), pp. 395-402.

Pretty, J. (1995) "Participatory learning for sustainable agriculture", World Development, 23(8), 1247-1263.

Reyntjens, F. (2005) "Burundi: A Peaceful Transition after a Decade of War?", African Affairs, 105(418), 117-35.

Sentamba, E. (2011) "Pour réussir la décentralisation au Burundi: s'attaquer frontalement aux obstacles systémiques", Cahier de l'IDEC, 3(8).

Sentamba, E. (2010) "Les élections de 2010 au Burundi: pari pour la démocratie ou pour le recul dans les affres du conflit", Cahier de l'IDEC, 3(6).

UNDP (2011) Sustainability and Equity: Human Development Report 2011, New York: United Nations Development Programme.

Uvin, P. (2008) "Local governance after war: Some reflections on donor behaviour in Burundi”, Praxis: The Fletcher Journal of Human Security, 23, 109-122.

Uvin, P. (2009) Life After Violence: A People's Story of Burundi, London and New York: Zed Books.

White, S.C. (1996) "Depoliticising development: the uses and abuses of participation”, Development in Practice, 6(1), 6-15.

World Bank (2011) Conflict, Security and Development: World Development Report 2011, Washington: World Bank.

Young, I.M. (2000) Inclusion and Democracy, Oxford: Oxford University Press. 